\title{
The development of directions of government regulation of the soybean production industry in modern economic conditions
}

\author{
K.M. Krivoshlykov ${ }^{1,}$, N.K. Vasilieva ${ }^{2}$, and E.Yu. Boyko ${ }^{1}$ \\ ${ }^{1}$ V.S. Pustvoit All-Russian Research Institute of Oil Crops, 350058 Krasnodar, Russian Federation \\ ${ }^{2}$ Kuban State Agrarian University named after I.T. Trubilin, 350044 Krasnodar, Russian Federation
}

\begin{abstract}
In modern conditions of the world economy's transformation, which caused significant changes in the foreign trade market environment, the current issue is the modernization of the agrifood policy of Russia to provide the national economy with the agricultural products of its own production, in particular with soybean. By increasing the means of state support and by overcoming structural problems, the soybean industry can become both a powerful driver of domestic economic growth and a key factor in the development of the world food markets in terms of Russia's focus on the global competitiveness of domestic products.
\end{abstract}

\section{Introduction}

The growth of agriculture importance in the process of ensuring food security of the Russian Federation in the context of the globalization of the world economy laid the basis for the development of Russia's agrifood policy in modern economic conditions. The achievements of goals of the Food Security Doctrine of the Russian Federation [1], consisting in the need of learning to use new production technologies and compensation of the existing protein deficit in the country along with the support of the soybean industry by the President of the Russian Federation V.V. Putin, who in his open speech (Blagoveshchensk) in 2014 noted: "I draw your attention that Russian soybean is the best soybean in the world, because it is not genetically modified, but natural, there is almost no such thing in the world anywhere except Russia" [2], gave a significant boot to the development of soybean cultivation in the country.

\section{Materials and methods}

V.F. Baranov, V.T. Sinegovskaya, V.M. Lucomets, N.I. Dvoryadkin, F.P. Khriplivy, V.M. Suslov and others made a significant contribution to the development of the conceptual basis of the establishment of the soybean production industry in the Russian Federation and the development of its economic component, both in terms of the crop production and its national economic use. Today, in the context of the development of negative trends in the

* Corresponding author: lab.econ@vniimk.ru 
political and economic aspects of international cooperation, it is more than ever important to establish the directions for the efficient and consistent development of the industry in the domestic and foreign markets, while also developing the export potential of the agroindustrial complex. In this regard, it is important to carry out research on the forms and methods of government regulation of both the fat-and-oil sector of the agroindustrial complex in general, and the soybean production industry in particular. All this determines the objective need to consider the problems stated in this work.

The methodological basis of the research was a review, analysis and generalization of analytical materials and legal framework on the problems of implementation of the provisions of the Food Security Doctrine, as well as the development of mechanism for government regulation of the soybean market in the Russian Federation in the face of global challenges. The main research methods were systematic and logical approaches, the method of theoretical knowledge, monographic method.

It is caused both by the need for import substitution of fodder and food soybean products, as well as the products of soybean processing, and by intensively increasing volume rates of this crop, which will contribute to the promotion of competitive domestic soybean on the international market.

One of the advantages of domestic soybean seed material is the environmentally safe traditional cultivation technology due to the current ban on the cultivation of genetically modified soybean varieties (GMO) in Russia.

The overcoming of the existing imbalance in the directions of use of processed soybean for food and technical purposes is the main goal of the sectoral program of the Russian Soybean Union (RSU) "The development of soybean production and processing in the Russian Federation for 2015-2020". This program suggests the development of soybean processing, a significant increase in the production of soybean milk and meat products, which provides the production of import-substituting food products based on soybean protein: isolates, concentrates, food composites and dietary supplements.

Another key event underlying the importance of the soybean industry as a promising one for Russia, was the signed agreement of the President of the Russian Federation V.V. Putin to a letter prepared with the participation of the RSU that asked for the state support for the soybean industry. This letter predicted the crop production by 2026 to 30 million tons, while, according to experts, soybean export could exceed $\$ 30$ billion per year (which is comparable to the Russian Federation revenues from gas export). At the same time, the required amount of financing for the efficient development of the soybean production industry, according to experts, is 195 billion rubles [3].

The providing of a continuous growth in the volume of manufactured agricultural products obtained as a result of the use of seeds of promising domestic varieties and hybrids is the key goal of the Federal scientific and development program (FSDP) for the development of agriculture for 2017-2025 [4]. Its main task is to develop conditions providing the competitiveness of the domestic agroindustrial complex by attracting investments in it. The program also makes provisions for the accelerated development of the scientific potential of the agroindustrial complex, while improving the system of training highly qualified personnel, supporting new directions in related fields of science and increasing the rate of technological modernization of the agricultural sector. The FSDP is executed through the implementation of subprograms - comprehensive scientific and technological programs (CSTP) for specific types of agricultural products, raw materials, and food.

The development of domestic technologies aimed at reducing the level of import dependence through the introduction and commercialization of the achievements of agricultural science became the goal of the CSTP. The aim of the subprogram is to unify the efforts of science, business, federal and regional executive authorities. The result of the 
programs should be the development of knowledge, which includes scientific and technical and (or) scientific results, products, technology transfer.

For example, in mid-2018, there was an approval of subprograms for the development of breeding and seed production of potatoes and sugar beet, which include the stages of the innovation cycle of products from obtaining scientific and technical results to their practical application and entry into market. Since the CSTP should include a research part and a business-oriented unit, developed with the participation of higher educational institutions and scientific organizations of the Russian Academy of Sciences, it is necessary to unify the work of all related parties.

Subsequently, in the fulfillment of the order of the President of the Russian Federation, and following the results of the Records of the council meeting for the implementation of the FSDP, the discussion of the upcoming work directions on the development of subprograms in 2019 predetermined the need for the development of the following CSTP: for animal fodder and feed supplements; for the development of the genetic potential of cattle; for breeding and seed growing of oil crops; for seed growing and breeding of vegetable crops. As a result of implementation of the FSDP, by 2025, $75 \%$ of the seeds used in production should be of domestic breeding.

According to the Decree of the President of the Russian Federation "On national goals and strategic objectives of the development of the Russian Federation for the period up to 2024 ", it is planned to ensure an accelerated growth rate of the domestic economy, to increase the competitiveness of agricultural products and the growth of its exports, in particular, products with the increased added value [5]. By 2024, the volume of agricultural products sold to the external market should amount to about $\$ 45$ billion per year, which is 2.2 times more than the level of $2017, \$ 8.4$ billion of which is accounted for by the fat-andoil industry.

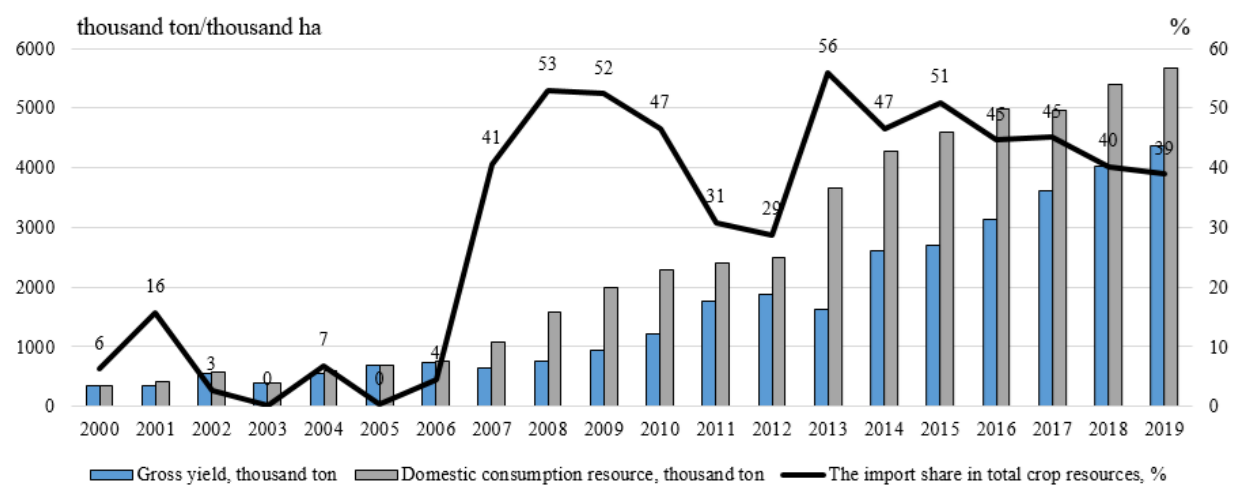

Fig. 1. The gross yield, domestic consumption resource and the import share in total soybean resources in the Russian Federation in 2000-2019.

The target of the development strategy of the agroindustrial complex of Russia is a significant improvement of balance of visible trade due to the integration of agricultural production and food industry, along with the optimization of the import structure.

The modern soybean market in the Russian Federation is characterized by an insufficient volume of production of this crop to meet the needs of the national economy, since in the period from 2000 to 2019 the production volume increased only 13 times, and the domestic consumption resource increased 16 times and amounted to 5.7 million tons. The maximum deviations in the rapid increase in the import share in the total resources of the crop were noted in 2007 and 2013, while, beginning from 2015, there has been a 
positive trend towards a decrease in the import share in total soybean resources from $51 \%$ to $39 \%$ in 2019 .

The development of the soybean production industry in the future can become a key export-oriented direction for the implementation of the set goals, since, as it was already noted, domestic soybean have a number of advantages and is in great demand on the world market. However, the uncertainty of subsequent sanctions against western countries as countering possible threats to Russia's national security in the event of price dumping, the application of unwarranted restrictions, subsidizing the export of products, etc. raises doubts among farmers about the further development of the industry's prospects.

Along with the high volatility of the ruble, the macroeconomic instability and the expectation of a high level of inflation, government interventions are currently aimed both at the short-term goals of maintaining profitability, modernization, and at the transition to a modern innovative model of the agroindustrial complex development [6]. It should be noted that the difficulties of the planning process of state support carried out within the framework of subprograms define the funding, the coordination of regional and federal interests, which leads to a high level of bureaucratization.

The principle of continuity and predictability in management decision-making is violated, the tools of agricultural industry regulation accumulated by the world practice are not fully employed [7]. Therefore, when ensuring food security of Russia, it is necessary to consider not only the criterion of independence from import, but also the economic and physical availability of products, namely, the quality, which is largely developed by taking into account the level of income of the population, the development of the logistics component, as well as the interregional food exchange.

There is still a high differentiation of agricultural producers in the country in terms of profitability and provision of material and technical resources for agricultural production. One of the reasons for the underperformance in the field of precision farming, urbanized agriculture and robotization is the insufficient financial capacity of small and medium businesses to introduce technological innovations [8]. At the same time, the depopulation of rural areas is still preserved along with a rather low level of prestige of agricultural professions and structural unemployment in rural areas. The shortage of qualified personnel in the agroindustrial complex is primarily associated with the unattractiveness of rural infrastructure for highly qualified specialists in this area.

The difficulties of the agricultural sector in Russia are largely defined by the failure to improve state support related to an underestimation of the importance of the role of the agroindustrial complex in the country's economy. Since at present the state budget of the country assigns about $2 \%$ of its expenditure side on the development of agricultural production, while in the USSR the level of support was $20 \%$, the level of support in developed countries is currently significantly higher than the domestic level: in the USA from 27 to $35 \%$, in Japan and Finland - up to $65-70 \%$ [9].

It should be noted that in the development of the raw material sector, in particular the soybean industry of the country, in addition to the above trends, there are systematic problems in the development of the seed market, which over the past decade has been largely dependent on foreign firms. The situation is worsened by the aggressive marketing policy of multinational companies, since distorted and inaccurate information support significantly affects the management decisions of farmers. For example, in 2019, according to the official data of the Federal state budgetary institution "Rosselkhoztsentr", $43 \%$ of soybean seeds sown in the Russian Federation were of foreign origin and $15 \%$ were nonvarietal. At the same time, the share of domestic seeds has decrease by 4 percentage points since 2018 and amounted to $42 \%$ in 2019.

Considering the current situation, the main condition for the implementation of the state strategy on import substitution is the competitive crop varieties developed by the leading 
Russian breeders meeting the current requirements if high-tech production and providing a high yield, as well as satisfying the needs of the fat-and-oil industry [10]. In Russia, there is a wide variety of parental material for breeding new soybean varieties.

The significant financial costs in developing new competitive varieties using traditional breeding methods are related to the purchase of equipment and breeding devices. The availability of technical means on farms in the required quantity to perform a full range of works in optimal agrotechnical terms plays an important role in ensuring food security in Russia.

The weak spot of the state breeding structures, acting as funded organizations and unable to receive loan benefits from commercial banks, is the lack of free financial resources. As for the requirements for the rate for obtaining loans for agricultural business, it is about $12 \%$ per annual and higher. Most of the agrarian business's margins are deposited in banks, along with significant amounts of state support for farmers in the form of loan subsidies.

The problem of developing the efficient functioning of the Russian breeding and seed growing program is a significant level of counterfeit seeds, which in turn requires prompt decisions at the legislative level, as well as the introduction of a system of penalties in case of violation of copyrights of breeders and patent holders. The mechanism for protecting breeding achievements in terms of effective control over unlicensed sales of varietal seeds by private seed companies and individuals is poorly developed.

However, the intensity of further development of the soybean production industry depends both on external factors and on the initiative of the enterprises of the fat-and-oil complex in terms of investing in breeding programs, as well as the use of developed protection mechanisms that ensure the stability of income of agricultural producers and increase their competitiveness through agricultural insurance and risk hedging.

\section{Results and discussion}

The classification of factors by the nature of their impact on the efficiency of the functioning of soybean production in modern agrifood conditions with the consideration of the peculiarities of industry management allowed us to define the key conditions, the implementation of which will contribute to increase in the competitiveness of the domestic seed market and the industry in general. 


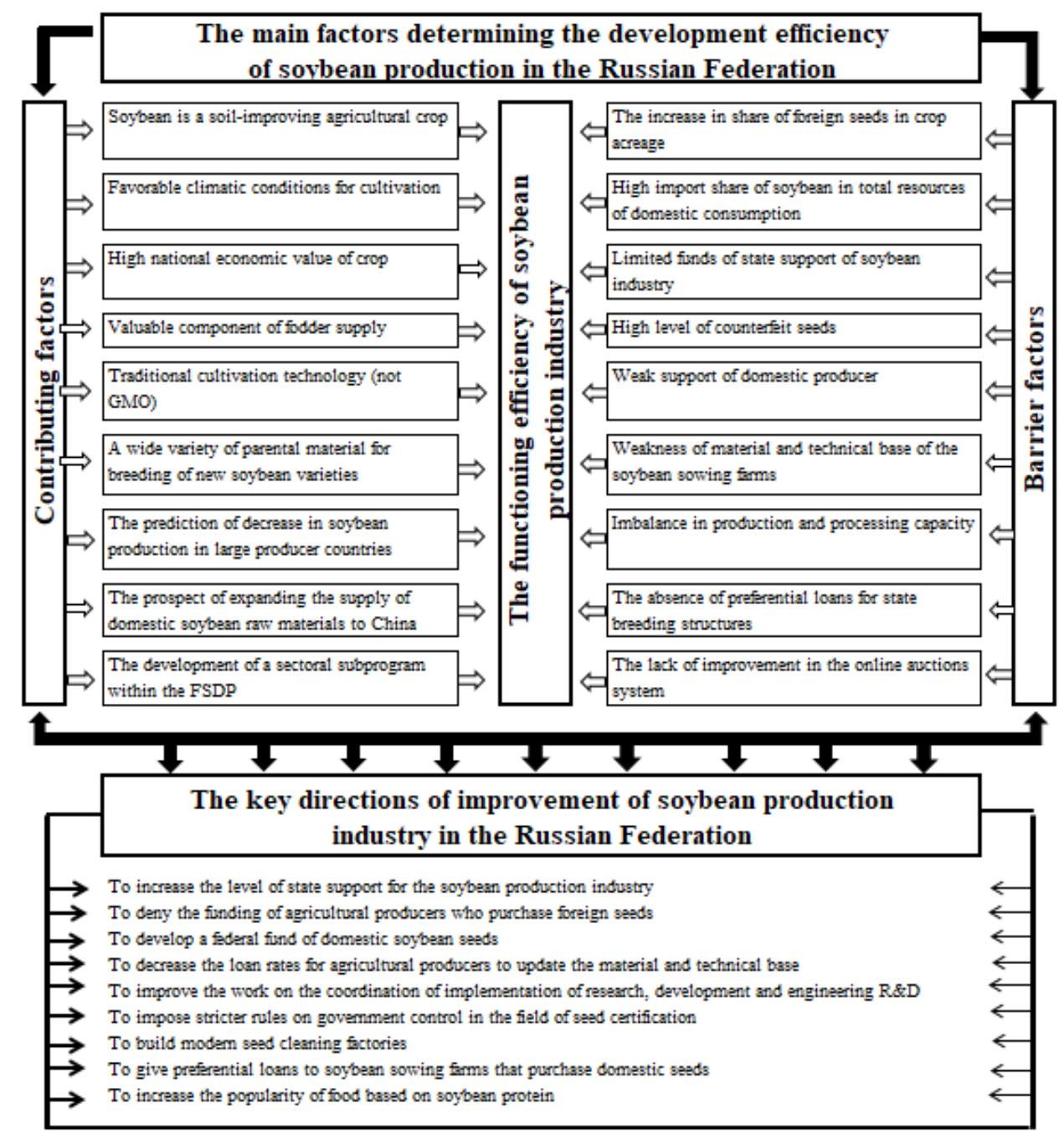

Fig. 2. The key directions of improvement of soybean production industry in the Russian Federation.

\section{Conclusions}

The overcoming of the structural problems of the soybean production industry, which in the future may become a key export-oriented direction of the fat-and-oil sector, by means of the complete exploit of the advantages of domestic breeding achievements, in our opinion, is achieved in the following key directions:

1. To increase the level of state support for domestic soybean sowing farms, which can be provided in the form of long-term subsidies, easy-term loans, or reduction of duties. At the same time, the state should be occupied not only with financial support, but also with the development of favorable legal field in order to provide the profitability of agricultural producers, which is required on an innovative basis for expanded reproduction.

2. To deny the funding of agricultural producers who purchase seeds of foreign breeding. The farms that buy expensive seeds of foreign companies are financially stable and additional subsidies contradict the principles of state support, which in turn imply the 
assistance to an entity that does not have the necessary amount of funds to attract resources for performing production activities.

3. At the expense of the budget of all levels, to establish a mechanism for the use and development of a federal seed fund, which provides an opportunity to ensure the safety of Russian farmers from various sanctions of other states, as well as to minimize agricultural risks of agricultural seed producers and domestic originators with an increase in production volumes of seeds as part of the import substitution strategy.

4. To impose stricter rules on government control in the field of seed certification, which lead to minimization of many negative factors, such as the breeding of poor-quality reproductions with low yield and the use of counterfeit seeds.

5. It is necessary to overcome the lobbying of banking interests in terms of decreasing loan rates for farmers and adjusting the priorities of the policy of state protection in connection with the world experience of developed countries, based on the need of agricultural producers to accelerate the modernization of technical equipment of the agroindustrial complex.

6. To monitor the carrying out of research and development work in the interests of the industry development, to develop new competitive domestic soybean varieties that provide high yield to meet the needs of the fat-and-oil industry.

7. To develop and implement investment projects for the building of the latest seed cleaning factories to attract state support and private business. The placement of factories should be based on the concentration of crop production and the scientific potential of the originator institutions of the industry segment.

8. The introduction of mechanism of preferential loans to agricultural producers for the purchase of Russian soybean seeds through the state banking system would solve significant problems of the state originator institutions, in particular, the commercialization of breeding discoveries.

9. To raise the popularity of a healthy lifestyle, as well as the demand for environmentally safe products based on soybean protein, which will contribute to the development of both soybean production and related agroindustrial sectors, primarily the meat and dairy industries, thereby ensuring the development of import-substituting food products.

Analyzing the key trends in the development of the soybean industry in Russia, it should be noted that this segment of the agrifood market has great growth potential, which can be reached with the implementation of a strategy aimed at import substitution in the domestic soybean market, which will contribute to an increase in the occupational level, growth of innovative development, which in turn will affect the increase in the education level. The closer attention of the state to agrarian transformations through modernization, as well as the intensification of the soybean production industry, will affect the increase in the level of competitiveness of the Russian agricultural products, ensure food and economic security of Russia, strengthen the country position on the world food market by increasing export potential.

\section{References}

1. About the approval of the Food Security Doctrine of the Russian Federation: the decree of the President of the Russian Federation of January 21, 2020, No 20. https://www.garant.ru/products/ipo/prime/doc/73338425/

2. Administration of the President of the Russian Federation: a meeting on the course of liquidation of the consequences of floods in the Far East: Official web-site of the President of Russia, 22.05.2014. http://www.kremlin.ru/events/president/news/21068 
3. The sectoral Program of the Russian Soybean Union 'Development of the production and processing of soybeans in the Russian Federation for 2015-2020': a protocol of the Ministry of Agriculture of the Russian Federation No 47 of November 12, 2014. http://www.ros-soya.su/public.aspx

4. About the approval of the Federal scientific and technical program on agriculture developemtn for 2017-2025: a decree of the President of the Russian Federation of July 21, 2016 No 350. http://government.ru/docs/29004/

5. About national iams and strategic tasks of the development of the Russian Federation till 2024: a decree of the President of the Russian Federation of May 7, 2018 No 204. http://kremlin.ru/acts/bank/43027

6. N.K. Vasilieva et al., Int. J. of Economic Res. 13(6), 2525 (2016)

7. Z.N. Stash et al., Int. J. of Applied Business and Economic Res. 15(23), 425 (2017)

8. Yu.I. Bershitsiy et al., Int. J.of Applied Business and Economic Res. 14(10), 7267 (2016)

9. V.V. Sidorenko, O.A. Makarevich, State regulation of the agrarian economy of Russia (A Kuban world, Krasnodar, 2017)

10. N.I. Zaitsev et al., Scientific and technical bulletin of VNIIMK, 2 (166), 3 (2016) 